\title{
Cross-sectional IgM and IgG profiles in SARS-CoV-2 infection
}

Authors: Tugba Ozturk, M.S., ${ }^{1}$ J Christina Howell, B.S., ${ }^{1}$ Karima Benameur, MD, ${ }^{1}$ Richard Ramonell, MD, ${ }^{2}$ Kevin S. Cashman, $\mathrm{PhD},{ }^{3}$ Shama Pirmohammed, BS, ${ }^{1}$ Leda C. Bassit, $\mathrm{PhD},{ }^{4}$ John D. Roback, Ph.D., ${ }^{5}$ Vincent C. Marconi, MD, ${ }^{6}$ Raymond F. Schinazi, PhD, DSc, ${ }^{4}$ Whitney Wharton, PhD, ${ }^{7}$ F. Eun-Hyung Lee, MD, ${ }^{2}$ William T Hu, M.D., Ph.D. ${ }^{1}$

${ }^{1}$ Departments of Neurology, ${ }^{2}$ Medicine - Division of Pulmonary, Allergy, Critical Care, and Sleep Medicine, ${ }^{3}$ Medicine-Rheumatology, ${ }^{4}$ Pediatrics and Center for AIDS Research, ${ }^{5}$ Laboratory Medicine and Pathology, ${ }^{6}$ Medicine - Division of Infectious Diseases, Emory University School of Medicine, and ${ }^{7}$ Emory University Nell Hodgson Woodruff School of Nursing, Atlanta, GA.

Article type: Original Article

Title character count (including spaces): 60

Abstract word count:248

Word count: 2441

Tables: 2

Figures: 2

References: 25

Running title: IgM and IgG in SARS-CoV-2

Corresponding author:

William $\mathrm{Hu}, \mathrm{MD}, \mathrm{PhD}$

Department of Neurology

615 Michael Street, 505F

Atlanta, GA 30322

Phone 404-727-4174

Fax 404-727-3728

Email:william.hu@emory.edu 
medRxiv preprint doi: https://doi.org/10.1101/2020.05.10.20097535; this version posted May 14, 2020. The copyright holder for this preprint (which was not certified by peer review) is the author/funder, who has granted medRxiv a license to display the preprint in perpetuity.

It is made available under a CC-BY-NC-ND 4.0 International license .

\begin{abstract}
Background: Accurate serological assays can improve the early diagnosis of severe acute respiratory syndrome coronavirus 2 (SARS-CoV-2) infection, but few studies have compared performance characteristics between assays in symptomatic and recovered patients.
\end{abstract}

Methods: We recruited 32 patients who had 2019 coronavirus disease (COVID-19; 18 hospitalized and actively symptomatic, 14 recovered mild cases), and measured levels of IgM (against the full-length S1 or the highly homologous SARS-CoV E protein) and IgG (against S1 receptor binding domain [RBD]). We performed the same analysis in 103 pre-2020 healthy adult control (HC) participants and 13 participants who had negative molecular testing for SARS-CoV-2.

Results: Anti-S1-RBD IgG levels were very elevated within days of symptom onset for hospitalized patients (median 2.04 optical density [OD], vs. 0.12 in HC). People who recovered from milder COVID19 only reached similar IgG levels 28 days after symptom onset. IgM levels were elevated early in both groups (median 1.91 and 2.12 vs. 1.14 OD in HC for anti-S1 IgM, 2.23 and 2.26 vs 1.52 in HC for anti-E IgM), with downward trends in hospitalized cases having longer disease duration. The combination of the two IgM levels showed similar sensitivity for COVID-19 as IgG but greater specificity, and identified 4/10 people (vs. $3 / 10$ by IgG) with prior symptoms and negative molecular testing to have had COVID19.

Conclusions: Disease severity and timing both influence levels of IgM and IgG against SARS-CoV-2, with IgG better for early detection of severe cases but IgM more suited for early detection of milder cases. 
medRxiv preprint doi: https://doi.org/10.1101/2020.05.10.20097535; this version posted May 14, 2020. The copyright holder for this preprint (which was not certified by peer review) is the author/funder, who has granted medRxiv a license to display the preprint in perpetuity.

It is made available under a CC-BY-NC-ND 4.0 International license .

\section{Introduction}

The 2019 novel coronavirus disease (COVID-19) pandemic began in December 2019,, ${ }^{1,2}$ and over 3 million people around the world have contracted the disease as of May 2020. Among both symptomatic and asymptomatic individuals with SARS-CoV-2, real time reverse-transcriptase polymerase chain reaction (rRT-PCR) remains the major confirmatory test. In the U.S., widespread rRT-PCR testing remains limited despite improvements. Moreover, rRT-PCR testing among clinical COVID-19 patients in China showed suboptimal sensitivity (positive in 72 of 104 sputum, 5 of 8 nasal swabs, 126 of 392 pharyngeal swabs). ${ }^{3}$ This is in keeping with previously identified challenges in the molecular diagnosis of the related SARS-CoV, including low viral count at onset, insufficient autopsy or neutralization tests as gold standard, and non-identical genetic strains. ${ }^{4,5}$ Several serological tests have been developed to detect immunoglobulins (IgG \& IgM) against viral proteins, ${ }^{6,7}$ but serological tests face usual challenges of delayed positivity, ${ }^{5}$ host immune function ${ }^{8}$ and cross-reactivity to other coronaviruses. ${ }^{9,10}$ Design of epidemiological surveys and treatment trials can therefore be greatly hindered by the absence of a consensus laboratory diagnostic algorithm.

Similar to other coronaviruses, SARS-CoV-2 is composed of four structures: envelope, membrane, nucleocapsid, and spike. ${ }^{2,11-13}$ The majority of amino acids unique to SARS-CoV-2 are located in the receptor binding domain (RBD) of the $\mathrm{S} 1$ subunit, ${ }^{14}$ and $\mathrm{S} 1$ as well as the RBD domain have been used in serological assays for COVID-19. ${ }^{6}$ Previous work on SARS-CoV found increased envelope (E) protein levels during viral replication, ${ }^{15}$ and E proteins from the two beta coronaviruses only differ by four amino acids. $^{2} \mathrm{~S} 1$ and $\mathrm{E}$ are therefore reasonable antigenic targets for serological assay development. Herein, we performed novel IgM (against the full-length SARS-CoV-2 S1 and highly homologous SARS-CoV E protein) assays and a commercially available IgG (against the S1-RBD) assay in hospitalized and recovered COVID-19 patients, and compared their serological profiles with pre-2020 healthy control (HC) participants and people with negative SARS-CoV-2 rRT-PCR results (previously symptomatic or never-symptomatic). 
medRxiv preprint doi: https://doi.org/10.1101/2020.05.10.20097535; this version posted May 14, 2020. The copyright holder for this preprint (which was not certified by peer review) is the author/funder, who has granted medRxiv a license to display the preprint in perpetuity.

\section{Materials and Methods}

\section{Standard Protocol Approvals, Registrations, and Patient Consents}

This study was approved by Emory University Institutional Review Board. Written consents were obtained from all participants or their legally authorized representatives (when appropriate).

\section{Study Participants}

Four groups of subjects were included in the study: 1) Hospitalized symptomatic patients with moderate-to-severe influenza-like illness (ILI) in keeping with COVID-19 confirmed by rRTPCR ( $n=18$, with 14 requiring artificial ventilation; samples collected during hospitalization a median of 10.5 days after symptom-onset, range 4-24 days); 2) people who recovered from mild self-limited COVID-19 (n=14; nine with (+)rRT-PCR, four with ILI following direct contact with confirmed COVID-19 cases but not eligible for rRT-PCR, and one with ILI following direct contact with confirmed COVID-19 cases but did not seek rRT-PCR; samples collected a median of 18.5 days after initial symptom onset, range 9-33); 3) pre-2020 HC (n=103) recruited through inflammation studies targeting the young (PI: WTH), ${ }^{16}$ middle-aged (PI: WW), ${ }^{17}$ or older (PI: WTH) adults; and 4) people who had (-)rRT-PCR results in $2020(\mathrm{n}=13$; two symptomatic at time of draw, eight recovered from mild self-limited ILI, and three never had any symptoms; none had follow-up rRT-PCR). Sample size was calculated based on one previous study ${ }^{6}$ when the current study began using a more conservative effect size (0.8 vs. $>1)$, with an estimated disease prevalence of 5\%-20\%. Plasma was collected from five hospitalized participants, nine mild participants, and all pre-2020 HC and those with (-)rRT-PCR. Serum was collected from the remaining 13 hospitalized participants and five mild participants. 
medRxiv preprint doi: https://doi.org/10.1101/2020.05.10.20097535; this version posted May 14, 2020. The copyright holder for this preprint (which was not certified by peer review) is the author/funder, who has granted medRxiv a license to display the preprint in perpetuity.

\section{Serological Assays}

A commercial anti-S1 receptor binding domain (RBD) IgG indirect ELISA assay (GenScript, Piscataway, NJ) was purchased and performed per manufacturer's protocol, except two plasma dilutions (1:16 and 1:64) were selected from a range of 1:8 - 1:256 performed in a subgroup of COVID-19 and pre-2020 HC subjects.

For IgM, we developed two novel assays. Synthetic SARS-CoV-2 S1 (230-01101-100, produced from E. coli) and SARS-related E (228-11400-2, produced from E. coli) proteins were purchased from RayBiotech (Peachtree Corners, GA). For IgM, $100 \mu \mathrm{L}$ of $2.5 \mu \mathrm{g} / \mathrm{mL}$ antigen in PBS was applied to standard 96-well plate at $4^{\circ} \mathrm{C}$ overnight. Six (out of 96) wells were coated only with 5\% albumin without S1/E. Plates were washed with PBS before blocking at room temperature for $1 \mathrm{hr}$ with 4\% non-fat dried milk (nfdm). Diluted plasma samples (1:64, 1:64, 1:256, 1:1024 in PBS containing 2\% nfdm and $0.1 \%$ Tween20) were loaded into blocked wells for $1 \mathrm{hr}$. Wells were then washed three times with PBS, and $50 \mu \mathrm{L}$ of 1:20,000 goat anti-human IgM fc (09-035-043, Jackson ImmunoResearch Laboratories, West Grove, PA) was added to each dilution condition for $30 \mathrm{~min}$. Wells were treated with strepavidin-HRP $(1: 200,50 \mu \mathrm{L}$ per well) for $20 \mathrm{~min}$ in the dark, washed, incubated with substrate mix for $20 \mathrm{~min}$ in the dark, and treated with reaction stop solution. Plates were then read at $450 \mathrm{~nm}$ (Molecular Devices, SpectraMax-M2) followed by background (570 nm) subtraction.

\section{Statistical Analyses}


medRxiv preprint doi: https://doi.org/10.1101/2020.05.10.20097535; this version posted May 14, 2020. The copyright holder for this preprint (which was not certified by peer review) is the author/funder, who has granted medRxiv a license to display the preprint in perpetuity.

It is made available under a CC-BY-NC-ND 4.0 International license .

All statistical analyses were performed using SPSS 26 (IBM SPSS, Armonk, NY) except for curve-fitting. Differences in optical densities (OD) were calculated at 1:16 dilution for the commercial IgG assay and 1:128 dilutions for all IgM assays. Chi-squared or Fisher's exact test was used to analyze differences between symptomatic and recovered COVID-19 patients, and Student's T-test was used to analyze differences between these two groups' age, anti-S1 and anti-E IgM levels, and $\log _{10}$-transformed anti-S1-RBD IgG due to its non-normal distribution. Duration of disease was available for $8 / 14(57 \%)$ of mild patients, and only available values were used for descriptive analysis.

Curve-fitting for relationships between antibody levels and time since symptom onset was performed in GraphPad Prism 8.4.2 (San Diego, CA). For each antibody, linear regression was compared against other higher order models (second- or third-order polynomial, and exponential growth for anti-S1-SBD IgG in recovered cases) based on Akaike Information Criteria. Except for anti-S1 IgM in hospitalized participants, linear functions provided better fit than more complex models.

Receiver-operating characteristic (ROC) curve analysis was first used to determine each serological test's ability to distinguish between symptomatic COVID-19 cases and 78 randomly selected pre-2020 HC. Threshold values from these ROC curve analyses were tested in the recovered cohort against 25 pre-2020 HC subjects. Given differences in the symptomatic and recovered groups, we further performed 100-fold ROC curve analysis using either anti-S1-RBD IgG or the product of anti-S1 and anti-E IgM. For each run, COVID-19 cases were randomly assigned to the training or test set at 1:1 ratio, and pre-2020 $\mathrm{HC}$ cases were randomly assigned to 
medRxiv preprint doi: https://doi.org/10.1101/2020.05.10.20097535; this version posted May 14, 2020. The copyright holder for this preprint (which was not certified by peer review) is the author/funder, who has granted medRxiv a license to display the preprint in perpetuity.

It is made available under a CC-BY-NC-ND 4.0 International license .

the training or test set at 2:1 ratio. Thresholds were automatically determined in the training set to maximize accuracy while maintaining balance between sensitivity and specificity, and applied to the test set to determine outcome sensitivity and specificity. Median threshold values from the 100-fold ROC curve analysis were used in the group of people with negative molecular testing.

Given the expected effect sizes, Bonferroni correction was used to adjust for multiple comparisons.

\section{Results}

Compared to hospitalized cases, mild cases were younger (median age 31.5 vs. 61.5 years, $\mathrm{t}(28)=3.593, \mathrm{p}=0.001)$ and did not have any African Americans ( 0 vs. $72 \%, \mathrm{p}<0.001)$. Compared to pre-2020 HC participants, hospitalized cases had greater anti-S1-RBD IgG ( $\log _{10}$ transformed due to non-normal distribution, $\mathrm{t}(31.7)=10.816$, p<0.001, Fig 1a), anti-S1 $\operatorname{IgM}(\mathrm{t}(119)=5.129$, $\mathrm{p}<0.001$, Fig 1b), and anti-E $\operatorname{IgM}(\mathrm{t}(119)=4.121, \mathrm{p}<0.001$, Fig 1c). The same was true among mild cases for anti-S1-RBD IgG $(\mathrm{t}(115)=4.042, \mathrm{p}=0.001$, Fig 1a), anti-S1 $\operatorname{IgM}(\mathrm{t}(117)=6.967$, $\mathrm{p}<0.001$, Fig $1 \mathrm{~b})$, and anti-E $\operatorname{IgM}(\mathrm{t}(115)=3.872, \mathrm{p}<0.001$, Fig 1c) compared to pre-2020 HC cases. Regression analysis showed women to have higher anti-S1 $(\mathrm{F}(1,128)=6.22, \mathrm{p}=0.014)$ and anti-E $(\mathrm{F}(1,128)=7.08, \mathrm{p}=0.009)$ IgM levels independent of COVID-19 status, but sex did not influence IgG levels.

Using these hospitalized cases and 78 pre-2020 HC, ROC analysis showed anti-S1 IgG to have AUC of 0.942 (95\% CI 0.883-1.000; Fig 2a), with a cut-off of 0.89 OD associated with 88.9\% sensitivity and $92.3 \%$ specificity. However, this cut-off identified only four of $14(28.6 \%)$ mild 
medRxiv preprint doi: https://doi.org/10.1101/2020.05.10.20097535; this version posted May 14, 2020. The copyright holder for this preprint (which was not certified by peer review) is the author/funder, who has granted medRxiv a license to display the preprint in perpetuity. It is made available under a CC-BY-NC-ND 4.0 International license .

participants, with the mild cases having much lower levels than hospitalized cases (0.71 vs. 1.77 , $t(30)=4.261, p=0.0002$, Fig 1a). Linear regression analysis (which better fit data than higher order polynomials) of the cross-sectional cohorts showed the mild cases' IgG levels to rise at the same rate (slope 0.042, 95\% CI: 0.009-0.075) as in the hospitalized cohort (slope 0.059, 95\% CI: 0.008-0.110) but lagged the latter by 28 days. In contrast, neither anti-S1 $\operatorname{IgM}(\mathrm{t}(30)=1.703$, $\mathrm{p}=0.099)$ nor anti-E $\operatorname{IgM}(\mathrm{t}(30)=0.190, \mathrm{p}=0.850)$ differed between mild and hospitalized cases, although IgM levels had a downward trend with longer disease duration in the hospitalized cases. Extrapolating the linear $\operatorname{IgG}(\mathrm{OD}=1.04+0.059 *$ days $)$ and the second-order anti-S1 IgM $\left(\mathrm{OD}=2.16-0.00348 *(\text { days-12.2)-0.00699*(days-12.2) })^{2}\right)$ curves among hospitalized participants showed a pre-symptomatic incubation period of 16 days vs. 5.6 days.

ROC analysis of anti-S1 IgM (AUC=0.852, 95\% CI of 0.739-0.965) with a cut-off of 1.37 OD was associated with sensitivity of $94.4 \%$, specificity of $69.2 \%$, and detection of $13 / 14(92.8 \%)$ mild participants; anti-E IgM (AUC=0.807, 95\% CI of 0.707-0.907) with a cut-off of $2.00 \mathrm{OD}$ was associated with sensitivity of $66.7 \%$, specificity of $79.5 \%$, and detection of $9 / 14(64.2 \%)$ mild participants. Because anti-S1 IgM is more sensitive while anti-E IgM is more specific, we multiplied the two IgM levels to achieve a balance between sensitivity and specificity (Table 2).

As an alternative to using a training cohort consisting of entirely hospitalized cases, we performed 100-fold simulation using a training cohort of randomly selected COVID-19 and pre2020 HC participants (1:1 and 2:1 distribution between the training and test groups, Fig 2b). This analysis showed - in the test groups - a median sensitivity and specificity of $82.1 \%$ and 86.0\% for anti-S1 x anti-E IgM, vs. 82.4\% and 76.5\% for anti-S1-RBD IgG. The combined IgM 
medRxiv preprint doi: https://doi.org/10.1101/2020.05.10.20097535; this version posted May 14, 2020. The copyright holder for this preprint (which was not certified by peer review) is the author/funder, who has granted medRxiv a license to display the preprint in perpetuity.

It is made available under a CC-BY-NC-ND 4.0 International license .

was more specific than $\operatorname{IgG}(\mathrm{t}(189.95)=8.393, \mathrm{p}<0.0001)$, but the two assays had similar sensitivity $(\mathrm{t}(198)=0.669, \mathrm{p}=0.504)$. Median thresholds of $3.58 \mathrm{OD}^{2}$ and 0.31 OD identified seven and six of the 13 (-) rRT-PCR participants as having positive serology, with four having elevated levels of both. Taking into account days from symptom onset among those who reported ILI symptoms ( $n=10)$, four had elevated IgM product and three of the four also had elevated IgG levels.

\section{Discussion}

The diagnosis and sero-surveillance of COVID-19 can be challenging. While small numbers of (+)rRT-PCR patients had high antibody titers against the S1 protein, ${ }^{6}$ patients who recovered the focus of any sero-survey - have not been systemically investigated. Here we show that a serological assay with reactivity against the most commonly targeted antigen (S1-RBD) had high sensitivity and specificity among hospitalized participants, but its sensitivity dramatically diminished in participants with mild COVID-19 during the first month after symptom onset. The lower anti-S1-RBD IgG levels may be related to milder severity, shorter disease duration, or both. In contrast, IgM levels were more comparable between symptomatic and recovered patients, although only more severe cases showed lower IgM levels with greater disease duration. Because of the time-dependent variability in these antibody levels, the combined IgM levels had greater specificity than IgG in detecting hospitalized and mild participants without loss in sensitivity during the first month. Early $\operatorname{IgM}$ and $\operatorname{IgG}$ profiles should be tested for their predictive value in distinguishing between severe (elevated $\operatorname{IgM}$ and $\mathrm{IgG}$ ) and mild (elevated IgM, normal $\mathrm{IgG}$ ) outcomes in a prospective cohort. 
medRxiv preprint doi: https://doi.org/10.1101/2020.05.10.20097535; this version posted May 14, 2020. The copyright holder for this preprint (which was not certified by peer review) is the author/funder, who has granted medRxiv a license to display the preprint in perpetuity.

It is made available under a CC-BY-NC-ND 4.0 International license .

A diagnostic algorithm using IgG levels trained on our hospitalized participants performed poorly to detect those who had mild COVID-19. This is generally in keeping with results from China showing low or medium-low neutralizing antibody titers in $47 \%$ of patients who recovered from mild COVID-19, ${ }^{18}$ although it is difficult to interpret whether the neutralizing antibodies identified represented $\mathrm{IgM}$, IgG, or both. The slow rise in $\mathrm{IgG}$ levels has also been reported by the UK National COVID Testing Scientific Advisory Panel using a novel assay against the SARS-CoV-2 trimeric spike protein, ${ }^{7}$ and was previously observed in SARS-CoV cases. ${ }^{19}$ The longer persistence of IgM may then be a corollary of the slow IgG increases, with long-lived antigen-induced plasma cells ${ }^{20}$ implicated in similar IgM persistence in other viral ${ }^{21,22}$ and nonviral $^{23}$ infections. Questions remain regarding whether the hospitalized severe cases have a long pre-symptomatic incubation period with slopes similar to their $\operatorname{Ig} M$ and $\operatorname{Ig} G$ profiles during the symptomatic phase, with the extrapolated incubation period (5.6 days) from the IgM curve more in keeping with current knowledge than the extrapolated value (14 days) from IgG. It also remains to be seen whether mild cases' $\operatorname{IgM}$ and $\operatorname{IgG}$ profiles would follow those of severe cases months out from their symptomatic phase. Finally but importantly, the expected heterogeneity in anti-S1-RBD IgG within hospitalized and mild cases needs detailed investigation as it may account for differences in neutralization potential, total IgG levels, and disease severity. Altogether, the two divergent temporal profiles of IgM and IgG suggested by our cross-sectional studies need further confirmation from longitudinal within-individual studies whose results will have significant implications in viral surveillance, post-exposure immunity, and vaccine development. 
medRxiv preprint doi: https://doi.org/10.1101/2020.05.10.20097535; this version posted May 14, 2020. The copyright holder for this preprint (which was not certified by peer review) is the author/funder, who has granted medRxiv a license to display the preprint in perpetuity.

It is made available under a CC-BY-NC-ND 4.0 International license .

These studies also highlight the importance of harmonizing serological testing methods and findings among COVID-19 cohorts according to symptom onset and severity. Hospitalized cohorts are often used for assay development because they had the greatest access to rRT-PCR testing and, conversely, were most accessible to clinical researchers. The choice of serological test can therefore underestimate past exposure to SARS-CoV-2, over-estimate immunity for convalescent plasma, ${ }^{24}$ or influence the choice of point-of-care lateral flow assays in large serosurveillance studies. ${ }^{7}$ Until a gold standard better than rRT-PCR is confirmed, rapid development of a standardized cohort (including clinically suspected COVID-19 with and without rRT-PCR confirmation of various severity at multiple time points) with adequate reference biofluid samples is urgently needed to empirically assess the performance of novel as well as marketed serological tests.

While our study included repeated samples only in a few individuals and the overall cohort size is limited, the broad cross-sectional inclusion both symptomatic and recovered patients provide an overview of IgM and IgG profiles in COVID-19 relative to time since symptom onset. The over-representation of African Americans in the more severely ill cohort may mediate some differences in antibody profiles. ${ }^{25}$ Further work is also necessary to determine antibody levels, if measured early in disease course, can adequately predict severity of disease. However, IgG clearly has a role in confirming severe COVID-19 cases, and a commercially available option such as the one we used can accelerate broad diagnostic testing independent of, or in addition to, single-center efforts which are more difficult to standardize. Levels of $\operatorname{IgM}$ and IgG - against multiple viral proteins or different configurations of the same protein - should also be routinely measured during in vitro neutralization experiments and convalescent plasma trials. Finally, 
medRxiv preprint doi: https://doi.org/10.1101/2020.05.10.20097535; this version posted May 14, 2020. The copyright holder for this preprint

(which was not certified by peer review) is the author/funder, who has granted medRxiv a license to display the preprint in perpetuity.

It is made available under a CC-BY-NC-ND 4.0 International license .

because we found a complex relationship between antibody levels, disease severity, and time since symptom onset, we urge extreme caution in using point-of-care or a single serologic assay to inform public policies.

\section{Author contribution/Acknowledgments}

TO, JCH, VCM, RFS, and WTH contributed conception and design of the study; TO, JCH, KB, RPR, KSC, LCB, VCM, JDR, WW, FEL, and WTH contributed to acquisition, analysis, and interpretation of the data; WTH performed the statistical analysis; TO, JCH, and WTH drafted the manuscript; KB, RPR, KSC, LCB, JDR, VCM, WW, and FEL provided critical revisions for important intellectual content; all authors read and approved the submitted version.

\section{Declaration of interests}

Dr. Hu and Emory University have licensed the IgM assay panel for SARS-CoV-2, have a patent on the CSF-based diagnosis of FTLD-TDP, and have a patent pending on the CSF-based prognosis of spinal muscular atrophy; Dr. Hu has consulted for ViveBio, LLC, AARP, Inc, and Biogen, Inc.; and has received research support from Fujirebio US. Dr. Lee is the founder of MicroB-plex, Inc and has research grants with Genentech.

\section{Acknowledgements}

This work was supported by National Institutes of Health grants R01 AG 054046, R01 AG054991, and T32HL116271. 
medRxiv preprint doi: https://doi.org/10.1101/2020.05.10.20097535; this version posted May 14, 2020. The copyright holder for this preprint (which was not certified by peer review) is the author/funder, who has granted medRxiv a license to display the preprint in perpetuity.

\author{
It is made available under a CC-BY-NC-ND 4.0 International license.
}


medRxiv preprint doi: https://doi.org/10.1101/2020.05.10.20097535; this version posted May 14, 2020. The copyright holder for this preprint (which was not certified by peer review) is the author/funder, who has granted medRxiv a license to display the preprint in perpetuity.

\section{References}

1. Huang C, Wang Y, Li X, et al. Clinical features of patients infected with 2019 novel coronavirus in Wuhan, China. Lancet 2020;395:497-506.

2. Wu F, Zhao S, Yu B, et al. A new coronavirus associated with human respiratory disease in China. Nature 2020;579:265-9.

3. Wang W, Xu Y, Gao R, et al. Detection of SARS-CoV-2 in Different Types of Clinical Specimens. JAMA 2020.

4. Hadjinicolaou AV, Farcas GA, Demetriou VL, et al. Development of a molecular-beacon-based multi-allelic real-time RT-PCR assay for the detection of human coronavirus causing severe acute respiratory syndrome (SARS-CoV): a general methodology for detecting rapidly mutating viruses. Arch Virol 2011;156:671-80.

5. Wu HS, Chiu SC, Tseng TC, et al. Serologic and molecular biologic methods for SARS-associated coronavirus infection, Taiwan. Emerg Infect Dis 2004;10:304-10.

6. Amanat F, Nguyen THO, Chromikova V, et al. A serological assay to detect SARS-CoV-2 seroconversion in humans. medRxiv 2020.

7. Adams ER, Anand R, Andersson MI, et al. Evaluation of antibody testing for SARS-Cov-2 using ELISA and lateral flow immunoassays. medRxiv 2020.

8. Wang $\mathrm{Y}$, Sun $\mathrm{S}$, Shen $\mathrm{H}$, et al. Cross-reaction of SARS-CoV antigen with autoantibodies in autoimmune diseases. Cell Mol Immunol 2004;1:304-7.

9. Patrick DM, Petric M, Skowronski DM, et al. An Outbreak of Human Coronavirus OC43 Infection and Serological Cross-reactivity with SARS Coronavirus. Can J Infect Dis Med Microbiol 2006;17:330-6.

10. Ou X, Liu Y, Lei X, et al. Characterization of spike glycoprotein of SARS-CoV-2 on virus entry and its immune cross-reactivity with SARS-CoV. Nat Commun 2020;11:1620.

11. Masters PS, Kuo L, Ye R, Hurst KR, Koetzner CA, Hsue B. Genetic and molecular biological analysis of protein-protein interactions in coronavirus assembly. Adv Exp Med Biol 2006;581:163-73.

12. Mortola E, Roy P. Efficient assembly and release of SARS coronavirus-like particles by a heterologous expression system. FEBS Lett 2004;576:174-8.

13. Wang $\mathrm{C}$, Zheng $\mathrm{X}$, Gai W, et al. MERS-CoV virus-like particles produced in insect cells induce specific humoural and cellular imminity in rhesus macaques. Oncotarget 2017;8:12686-94.

14. Wan Y, Shang J, Graham R, Baric RS, Li F. Receptor Recognition by the Novel Coronavirus from Wuhan: an Analysis Based on Decade-Long Structural Studies of SARS Coronavirus. J Virol 2020;94.

15. Nieto-Torres JL, Dediego ML, Alvarez E, et al. Subcellular location and topology of severe acute respiratory syndrome coronavirus envelope protein. Virology 2011;415:69-82.

16. Hu WT, Howell JC, Ozturk T, et al. CSF Cytokines in Aging, Multiple Sclerosis, and Dementia. Front Immunol 2019;10:480.

17. Wharton W, Kollhoff AL, Gangishetti U, et al. Interleukin 9 alterations linked to alzheimer disease in african americans. Ann Neurol 2019;86:407-18.

18. Wu F, Wang A, Liu M, et al. Neutralizing antibody responses to SARS-CoV-2 in a COVID-19 recovered patient cohort and their implications. medRxiv 2020.

19. Bao $\mathrm{M}$, Zhang $\mathrm{Y}$, Wan $\mathrm{M}$, et al. Anti-SARS-CoV immunity induced by a novel $\mathrm{CpG}$ oligodeoxynucleotide. Clin Immunol 2006;118:180-7.

20. Bohannon C, Powers R, Satyabhama L, et al. Long-lived antigen-induced IgM plasma cells demonstrate somatic mutations and contribute to long-term protection. Nat Commun 2016;7:11826.

21. Murray KO, Garcia MN, Yan C, Gorchakov R. Persistence of detectable immunoglobulin M antibodies up to 8 years after infection with West Nile virus. Am J Trop Med Hyg 2013;89:996-1000.

22. Chien YW, Liu ZH, Tseng FC, et al. Prolonged persistence of IgM against dengue virus detected by commonly used commercial assays. BMC Infect Dis 2018;18:156. 
medRxiv preprint doi: https://doi.org/10.1101/2020.05.10.20097535; this version posted May 14, 2020. The copyright holder for this preprint (which was not certified by peer review) is the author/funder, who has granted medRxiv a license to display the preprint in perpetuity. It is made available under a CC-BY-NC-ND 4.0 International license.

23. Kalish RA, McHugh G, Granquist J, Shea B, Ruthazer R, Steere AC. Persistence of immunoglobulin $M$ or immunoglobulin $G$ antibody responses to Borrelia burgdorferi $10-20$ years after active Lyme disease. Clin Infect Dis 2001;33:780-5.

24. Bloch EM, Shoham S, Casadevall A, et al. Deployment of convalescent plasma for the prevention and treatment of COVID-19. J Clin Invest 2020.

25. Bernard NJ. Double-negative B cells. Nat Rev Rheumatol 2018;14:684. 


\section{Figure Legends}

Figure 1. Serological assay results of COVID-19 participants. Anti-S1-RBD IgG (a), anti-S1 $\operatorname{IgM}(\mathrm{b})$, and anti-E IgM (c) levels were analyzed in pre-2020 HC participants (gray circles), hospitalized symptomatic COVID-19 participants with severe (black circles) or mild-tomoderate (red circles) disease, and COVID-19 participants who had recovered from mild selflimited disease (blue circles). Antibody levels for COVID-19 were plotted according to selfreported symptom onset. Thin lines between represent serial sampling from the same subject, and thick lines with $95 \%$ confidence intervals represent best fit lines.

Figure 2. Receiver operating characteristics curve analysis showing performance differences between hospitalized and mild participants (a). 100-fold ROC curve analysis showed similar sensitivity between anti-S1-RBD IgG and the combination IgM (product of anti-S1 and anti-E $\operatorname{IgM})$, but the latter has greater specificity $(\mathrm{p}<0.0001)$. 
Table 1. Demographic and other information included in the current study. Categorical and continuous variables which differed between groups are shown in bold. * Comparison between symptomatic, recovered, and (-)rRT-PCR groups only. $\dagger$ Different between hospitalized and mild cases at $\mathrm{p}<0.005$. $\dagger \dagger \mathrm{n}=8$ for mild and $\mathrm{n}=10$ for $(-) \mathrm{RT}-\mathrm{PCR}$.

\begin{tabular}{|c|c|c|c|c|c|}
\hline & $\begin{array}{l}\text { Hospitalized } \\
\qquad n=18\end{array}$ & $\begin{array}{l}\text { Mild } \\
n=14\end{array}$ & $\begin{array}{c}\text { Pre-2020 HC } \\
n=103\end{array}$ & $\begin{array}{c}\text { (-)rRT-PCR } \\
n=13\end{array}$ & $\mathrm{p}$ \\
\hline Female $(\%)$ & $7(39 \%)$ & $6(43 \%)$ & $61(59.2 \%)$ & $9(69 \%)$ & 0.434 \\
\hline Age, median (range), yr & $\begin{array}{c}61.5 \dagger \\
(30-81)\end{array}$ & $\begin{array}{l}31.5 \dagger \\
(26-81)\end{array}$ & $\begin{array}{c}62 \\
(24-87)\end{array}$ & $\begin{array}{c}35.8 \\
(29-63)\end{array}$ & $<0.0001$ \\
\hline Race & & & & & $<0.0001$ \\
\hline Asian & $2(11 \%)$ & 0 & $2(2 \%)$ & $1(8 \%)$ & \\
\hline African American & $13(72 \%) \dagger$ & $\mathbf{0 \dagger}$ & $15(14 \%)$ & $3(23 \%)$ & \\
\hline Non-Hispanic Caucasian & $3(17 \%)$ & $12(86 \%)$ & $82(80 \%)$ & $8(61 \%)$ & \\
\hline Hispanic & 0 & $1(7 \%)$ & 0 & $1(8 \%)$ & \\
\hline Other & 0 & $1(7 \%)$ & $4(4 \%)$ & 0 & \\
\hline Inpatient/outpatient* & $18 / 0$ & $1 / 13$ & - & $\mathbf{0} / \mathbf{1 3}$ & $<0.001$ \\
\hline $\begin{array}{l}\text { Days since symptom onset, } \\
\text { median (range)* }\end{array}$ & $\begin{array}{l}10.5 \\
(4-24)\end{array}$ & $\begin{array}{l}18.5 \\
(9-33)\end{array}$ & - & $\begin{array}{c}17 \\
(2-43)\end{array}$ & $0.057 *$ \\
\hline $\begin{array}{l}\text { Respiratory failure } \\
\text { requiring intubation }(\%)\end{array}$ & $14(78 \%)$ & $\mathbf{0}$ & - & $\mathbf{0}$ & $<0.001$ \\
\hline $\begin{array}{l}\text { Duration of disease, median } \\
\text { (range), days }\end{array}$ & $\begin{array}{c}10.5 \\
(4-24)\end{array}$ & $\begin{array}{c}11 \\
(4-23) \dagger\end{array}$ & & $\begin{array}{c}4.5 \\
(1-30)\end{array}$ & 0.126 \\
\hline Clinical symptoms* & & & - & & \\
\hline Cough & $16(89 \%)$ & $9(64.3 \%)$ & - & $6(46 \%)$ & 0.036 \\
\hline Fever/chills & $15(83 \%)$ & $10(71 \%)$ & - & $5(38 \%)$ & 0.030 \\
\hline Shortness of breath & $13(72 \%)$ & $6(43 \%)$ & - & $3(23 \%)$ & 0.022 \\
\hline
\end{tabular}




\begin{tabular}{|c|c|c|c|c|c|}
\hline Myalgia & $6(33 \%)$ & $9(64 \%)$ & - & $4(31 \%)$ & 0.130 \\
\hline Headaches & $5(28 \%)$ & $8(57 \%)$ & - & $2(15 \%)$ & 0.058 \\
\hline Sore throat & $2(11 \%)$ & $6(43 \%)$ & - & $5(38 \%)$ & 0.096 \\
\hline Nasal congestion/rhinorrhea & $2(11 \%)$ & $6(43 \%)$ & - & $4(31 \%)$ & 0.121 \\
\hline Diarrhea & $2(11 \%)$ & $3(21 \%)$ & - & $3(23 \%)$ & 0.630 \\
\hline Anosmia & $\mathbf{0} \dagger$ & $6(43 \%) \dagger$ & - & $\mathbf{0}$ & $<0.001$ \\
\hline Fatigue & $1(6 \%)$ & $2(14 \%)$ & - & $2(15 \%)$ & 0.623 \\
\hline Vomiting & 0 & $1(7 \%)$ & - & 0 & 0.323 \\
\hline Never symptomatic* & 0 & 0 & - & $3(23 \%)$ & 0.021 \\
\hline $\begin{array}{l}\text { SARS-CoV-2 detected by } \\
\text { rRT-PCR* }\end{array}$ & $16 / 16$ & 9/9 & - & $\mathbf{0} / 13$ & $<0.001$ \\
\hline $\begin{array}{l}\text { Anti-S1-RBD IgG, median } \\
\text { (range), OD }\end{array}$ & $\begin{array}{c}2.04 \dagger \\
(0.15-2.73)\end{array}$ & $\begin{array}{c}0.37 \dagger \\
(0.08-2.09)\end{array}$ & $\begin{array}{c}0.12 \\
(0.01-2.09)\end{array}$ & $\begin{array}{c}0.28 \\
(0.02-0.91)\end{array}$ & $<0.001$ \\
\hline $\begin{array}{l}\text { Anti-S1 IgM, median (range) } \\
\text { OD }\end{array}$ & $\begin{array}{c}1.91 \\
(0.31-2.95)\end{array}$ & $\begin{array}{c}2.12 \\
(0.98-2.78)\end{array}$ & $\begin{array}{c}1.14 \\
(0.33-2.53)\end{array}$ & $\begin{array}{c}2.07 \\
(0.25-3.36)\end{array}$ & $<0.001$ \\
\hline $\begin{array}{l}\text { Anti-E IgM, median (range), } \\
\text { OD }\end{array}$ & $\begin{array}{c}2.23 \\
(1.03-3.04)\end{array}$ & $\begin{array}{c}2.26 \\
(1.28-3.67)\end{array}$ & $\begin{array}{c}1.52 \\
(0.15-3.04)\end{array}$ & $\begin{array}{c}2.58 \\
(0.46-3.10)\end{array}$ & $<0.001$ \\
\hline
\end{tabular}


medRxiv preprint doi: https://doi.org/10.1101/2020.05.10.20097535; this version posted May 14, 2020. The copyright holder for this preprint (which was not certified by peer review) is the author/funder, who has granted medRxiv a license to display the preprint in perpetuity.

It is made available under a CC-BY-NC-ND 4.0 International license .

Table 2. Performance characteristics of three serological tests in the hospitalized (training, vs. 78 pre$2020 \mathrm{HC}$ ) and mild (validation, vs. 25 pre-2020 HC) cohorts, using thresholds developed in the hospitalized cohorts.

\begin{tabular}{c|c|c|c|c|c|c|c|c}
\hline & \multicolumn{2}{|c|}{ anti-S1-RBD IgG } & \multicolumn{2}{c|}{ anti-S1 IgM } & \multicolumn{2}{c|}{ anti-E IgM } & \multicolumn{2}{c}{ anti-S1 IgM x a } \\
\hline & Hospitalized & Mild & Hospitalized & Mild & Hospitalized & Mild & Hospitalized \\
\hline Y (\%) & $\mathbf{8 8 . 9 \%}$ & $28.6 \%$ & $\mathbf{9 4 . 4 \%}$ & $\mathbf{9 2 . 8 \%}$ & $66.7 \%$ & $64.3 \%$ & $77.8 \%$ \\
\hline y $(\%)$ & $\mathbf{9 2 . 3 \%}$ & $\mathbf{9 6 . 4 \%}$ & $69.0 \%$ & $64.0 \%$ & $\mathbf{7 9 . 5 \%}$ & $64.0 \%$ & $\mathbf{8 2 . 0 \%}$ & $50.0 \%$ \\
\hline & $72.7 \%$ & $\mathbf{8 0 . 0 \%}$ & $41.5 \%$ & $59.1 \%$ & $42.8 \%$ & $50.0 \%$ & $50.0 \%$ \\
\hline & $\mathbf{9 7 . 3 \%}$ & $73.0 \%$ & $\mathbf{9 8 . 2 \%}$ & $\mathbf{9 4 . 1 \%}$ & $\mathbf{9 1 . 2 \%}$ & $76.2 \%$ & $\mathbf{9 4 . 1 \%}$ & \\
\hline
\end{tabular}



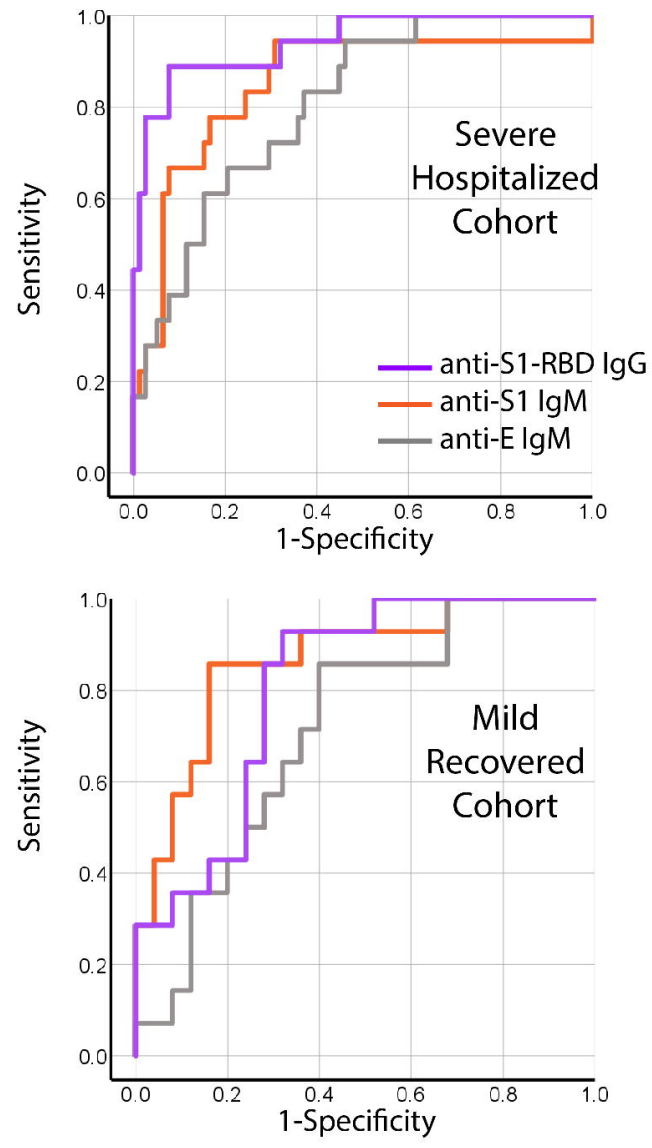

b

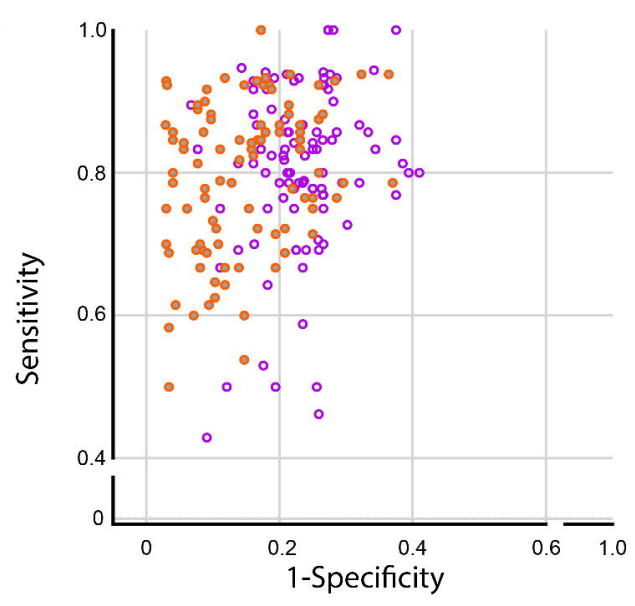

